\title{
Analyzing the Impact of Information and Communication Technology (ICT) on Restructuring of Public Service in Nigeria.
}

\author{
Aminu Mohammed Lawan, Razlini Mohd Ramli, Siti Zuliha Razali
}

\begin{abstract}
The purpose of this paper is to examines the impact of Information and Communication Technology (ICT) on restructuring of public service in Nigeria. The globalization policy assert that the public service of the developing countries must be restructured to comply with new technology i.e. the information and communication technology for efficiency and productivity. This is to say that the public servants must have a basic knowledge of ICT usage in their organization or otherwise they will lose their job and replace with high skilled employees. This study conducted systematic review of relevant literature on ICT and public service restructuring and come up with methodological result. The findings show that the idea of new public management (NPM) was introduced. This give emphasis on engagement of highly skilled workers that are ICT compliant will be retained into the public service to replace low skilled and manual employees. Finally, the paper recommends the need to improve service quality in public sector through the training and retraining of employees in line with new technology.
\end{abstract}

Index Terms: Information and Communication Technology (ICT), Public Service, Restructuring, Public Servant, Nigeria.

\section{INTRODUCTION}

The information and communication technology (ICT) is receiving a widespread acceptance globally, especially in human resource development and delivery of service quality to the public. Several studies have analyzed the importance of information and communication technology (ICT) on restructuring of public service.

The literature indicates that in developing countries like Nigeria, the information and communication technology (ICT) contribute to the enhancement of their socioeconomic conditions (Mann et al., 2004) (Walsham \& Sahay, 2006); (Walsham, Robey, \& Sahay, 2007). These scholars aim at realizing the perceptions of desirable world orders, such as Sen's theory of capabilities (Kleine \& Unwin, 2009); (Madon, 2004); Zheng, 2009) or the United Nations' Millennium Goal vision of eradicating poverty (Gilhooly, 2005);(Avgerou, 2010)

Other scholars state the two main effects of information

Revised Manuscript Received on September 22, 2019

Aminu Mohammed Lawan, School of Social Sciences, Universiti Sains Malaysia. Penang, Malaysia,. aminuhadi2@gmail.com

Razlini Mohd Ramli, School of Social Sciences, Universiti Sains Malaysia. Penang, Malaysia.

Siti Zuliha Razali, School of Social Sciences, Universiti Sains Malaysia Penang, Malaysia. and communication technology (ICT) application on labour as follows: the compensation effect and the substitution effect. In the first place, ICT can replace employees either directly (such as, robots substitute workers by taken over responsibilities performed by them previously) or indirectly (for instance, through improved work efficiency, this reduce labour intensive in producing single of output). These effects are not limited to low-skilled workers: medium and high-skilled workers are affected as well1 (Autor et al., 2003(Autor, Levy, \& Murnane, 2003); Acemoglu and Autor, 2011; Brynjolfsson and McAfee, 2011 and 2014). In the second place, a compensation effect may result from an increase in the demand for labour due to the ICT-driven gains in efficiency (and hence lower prices) or to the ICT-enabled product innovations, both of which lead to higher demand for firms' products. Which of the two effects prevails is subject to intense debate but is ultimately an empirical issue. Finally, ICT could affect the skill/occupation composition of employment (Falk and Biagi, 2016), though it may not have a systematic effect on overall employment (Aghion et. al., 2013);(Pantea, Sabadash, \& Biagi, 2017).

The main objective of this research is to examines the impact of Information and Communication Technology (ICT) on restructuring of public service in Nigeria.

\section{THE INFORMATION AND COMMUNICATION TECHNOLOGY (ICT) AND PUBLIC SERVICE IN NIGERIA}

The information and communication technology (ICT) play an important role in reforming public service in Nigeria especially in eGovernment system. It helps to streamline the government to block financial leakages and ensure effective and equitable use of resources.

One study done by Osagie (2011) found that, the ICT has to do with spreading of vital information that help to improve goods, service and financial capital among nations-states irrespective of their distance. Generating effective and efficient communication network, thus, globalization relies on information and communication network (Aziz Ali, 2009 in (Osagie, 2011)

Products built on otherwise improved by info-tech remain practical in almost all facet of life of Nigerians. The spreading of information

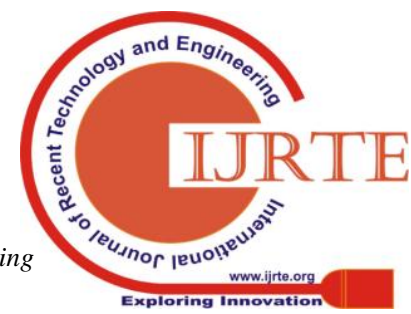


system and its application has been extremely speedy in Nigeria, many Nigerians even though the large number of them do not have access to computer devices. The lack of constant electricity supply resulted to inaccessibility of computers in Nigeria. Currently large number of Nigerians used a portable handset, digital mobile telephones that can easily operate than the analogue immobile telecommunication system.

There is mixed and inconclusive studies on the effect of ICT at firm level base on empirical evidence (Channells and Van Reenen, 2002; Vivarelli, 2014). There is a limited research on the effect of ICT on public service especially organisation level measures of ICT use within the organisation because of inadequate data (Bloom et al., 2011). Most literature emphasise on change in technology related to ICT like organisation innovations and process, report mixed, effects on employment, that it resulted to job destruction in the short run as theoretically suggested (Pianta, 2005; Vivarelli, 2014).

Moreover, ICT mostly reflects the inaccurate pointers of use of ICT and globally-comparable organisation-level data. To examines the effects of ICT on employment, organisation-level analysis has important measures because it does away with most biases as a result of aggregation. It is hard to get a good quality data representative of nation states economies talk less of regional economies (Pantea et al., 2017).

\section{RESTRUCTURING OF PUBLIC SERVICE}

Public service restructuring emerges because of conditionality attached with loans given to the developing countries by Bretton woods institutions of international monetary fund (IMF) and World Bank. To some section of the society, public service restructuring is regarded as downsizing, whereas others view it as civil service reforms (Anders, 2008). In developing countries some authors view it as human resources development or capacity building. The IMF and World Bank come out with policies for the reforms in public sector of developing countries that lead to downsizing, privatization and transparency. The economic crisis of 1980s brings about the stabilization and adjustment programme that emphasize on market efficiency unlike public sector reform (Bangura, 2000).

However, on the public service reform, the World Bank has focused on restructuring of civil service, pay and employment reform, privatization, decentralization and marketization of public services. The IMF on the other hand has concentrated on aggregate fiscal balances, transparent budgetary practices, expenditure controls and tax administration (Bangura, 2000). In developing countries like African states, they restricted their reforms to capacity building reforms. It deals with matters such as technical capabilities of public servants in monitoring and analysis of policies, recurrent expenditure costs, public investment and reforms on pay. Restructuring was done to ensure an increase accountability and transparency in public policy, also increase people's participation in quality services delivery. Citizens serves as instrument for the achievement of the above goals. Charters, Ombudsmen, servicom or service delivery, parliamentary plurality, independent judiciary, press freedom e.t.c. these ensure public transparency and accountability.

It is significant to view the relationship between the restructuring and the goals as one, instead of individual reform mechanism for each of the goals. Example fiscal reform mechanisms are more of ensuring efficiency, whereas the managerial restructuring leads to fiscal stability. However, based on these broad areas of the reforms and restructuring, the international financial institutions like IMF and world bank emphasize on fiscal stability then managerial efficiency, capacity building reform and public accountability (Bangura, 2000).

\section{METHODOLOGY}

This study employs systematic literature review method. The authors critically review the literature that are relevant to this study from secondary source. It comes out with methodological result of findings on analysing the impact of information and communication technology (ICT) on restructuring public service in Nigeria.

\section{FINDINGS}

Base on the findings of this study from the literature of information and communication technology (ICT) and restructuring of Nigerian public sector, the new technology (ICT) encourage better service delivery to Nigerian citizens. It helps in blocking the leakages and official corruption in public sector because of the e-government system. The findings from the literature also reveals that information technology usages are very vital to the public service in Nigeria because it improved productivity of workers.

\section{CONCLUSION}

The globalization policy assert that the public service of the developing countries must be restructured to comply with new technology i.e. the information and communication technology (ICT) for efficiency and productivity. This is to say that the public servants must have a basic knowledge of ICT usage in their organization or otherwise they will lose their job and replace with high skilled employees. The globalization policy of restructuring public service through ICT application will ensure efficiency. Because subjecting the government to intense competition may allow the states to function efficiently and effectively, this will overcome structural problems of public service.

Finally, the paper recommends the need to improve service quality in public sector through the training and retraining of employees in line with new technology. This is become necessary to avoid employee turnover and waste of public fund. There is need for government to provide adequate infrastructural facilities and adequate skilled manpower and conducive working environment for public service to operate effectively in the country.

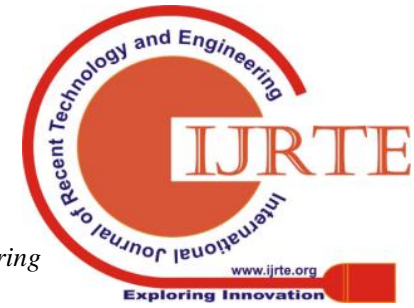




\section{REFERENCES}

[1] Anders, G. (2008). The Normativity of Numbers: World Bank and IMF Conditionality1. PoLAR: Political and Legal Anthropology Review, 31(2), 187-202.

[2] Autor, D. H., Levy, F., \& Murnane, R. J. (2003). The skill content of recent technological change: An empirical exploration. The Quarterly journal of economics, 118(4), 1279-1333.

[3] Avgerou, C. (2010). Discourses on ICT and development. Information Technologies \& International Development, 6(3), pp. 1-18.

[4] Bangura, Y. (2000). Public sector restructuring: the institutional and social effects of fiscal, managerial and capacity-building reforms. Retrieved from Geneva:

[5] Gilhooly, D. (2005). Innovation and investment. I-WAYS, Digest of Electronic Commerce Policy and Regulation, 28(3), 181-189.

[6] Kleine, D., \& Unwin, T. (2009). Technological Revolution, Evolution and New Dependencies: what's new about ict4d? Third World Quarterly, 30(5), 1045-1067.

[7] Madon, S. (2004). Evaluating the developmental impact of e-governance initiatives: an exploratory framework. The Electronic Journal of Information Systems in Developing Countries, 20(1), 1-13.

[8] Mann, A. E., Purvis, R. E., Mastrototaro, J. J., Causey, J. D., Henke, J., Hong, P., . . . Hite, B. T. (2004). Telemetered characteristic monitor system and method of using the same: Google Patents.

[9] Osagie, R. (2011). Globalization and human resource development in Nigeria. American Journal of Social and Management Sciences, 217-219.

[10] Pantea, S., Sabadash, A., \& Biagi, F. (2017). Are ICT displacing workers in the short run? Evidence from seven European countries. Information Economics and Policy, 39, 36-44.

[11] Vivarelli, M. (2014). Innovation, employment and skills in advanced and developing countries: A survey of economic literature. Journal of Economic Issues, 48(1), 123-154.

[12] Walsham, G., Robey, D., \& Sahay, S. (2007). Foreword: Special issue on information systems in developing countries. Mis Quarterly, 317-326.

[13] Walsham, G., \& Sahay, S. (2006). Research on information systems in developing countries: Current landscape and future prospects. Information technology for development, 12(1), 7-24.

\section{AUTHORS PROFILE}

I am Aminu Mohammed Lawan, belongs to School of Social Sciences, Universiti Sains Malaysia. and Department of Political Science, Yobe State University, Damaturu, Nigeria, aminuhadi2@gmail.com. My area of interest is technology management.

My name is Razlini Mohd Ramli, my affiliation is Department of Political Science, Yobe State University, Damaturu, Nigeria.my area of interest is Political sciences.

I am Siti Zuliha Razali, affiliation with Department of Political Science, Yobe State University, Damaturu, Nigeria. My area of interest is Politics and International Relations. 